\title{
Pussy Riot vs. Civil Obedience: A Critical Discourse Analysis of Two Texts
}

\author{
Volha Kananovich
}

In February 2012, at the height of that year's presidential campaign in Russia, a short video was uploaded to YouTube by a member of the Pussy Riot punk feminist band (Matveeva). The video featured four young women in brightly colored masks and short dresses in front of the altar of Russia's major Orthodox temple, the Cathedral of Christ the Savior in Moscow. Lifting their legs, kneeling and crossing themselves, the women lip-synced a "punk prayer" that they had set to the music of a sacred Orthodox song, ${ }^{1}$ in which they pleaded with the Virgin Mary to "drive Putin," who was running for his third presidential term, "away."

The clip, which also contained scenes from an earlier Pussy Riot performance in another cathedral, lasted a little less than two minutes. It was nearly twice as long as the actual performance, a fact revealed five months later in court, in which three Pussy Riot members identified by the police as the participants of that performance Nadezhda Tolokonnikova, Mariya Alyokhina, and Ekaterina Samutsevich - were put on trial and charged with hooliganism motivated by religious hatred ("Opublikovano"). Heavily covered by the domestic and international media ("O Pussy Riot"), accompanied by mass protests ("Pussy Riot Supporters"), comments and appeals from government officials (Nakamura and Weiner) and public figures ("Madonna Urges Russia"; "Yoko Ono Awards") around the world, the trial ended in August 2012. The women were found guilty and sentenced to two years in a penal colony ("Prigovor").

In October 2012, Samutsevich's term was converted into a suspended sentence (Tsoi and Ledniov). Tolokonnikova and Alyokhina were freed from prison three months before their scheduled release, in December 2013 ("Jailed Pussy Riot Activ- 
ists”). The reason for their release, as the Russian authorities emphasized, was a nationwide amnesty to commemorate the 20th anniversary of the Russian constitution, but it was interpreted by the band members as a PR stunt ("Freed Pussy Riot Activists”) before the Olympic Games that were hosted by Russia in February 2014.

The timing and the multitude of the conflicting interpretations of the performance have transformed the Pussy Riot affair - using the term that that Chilton made famous - into a "critical discourse moment" (12) that put issues of religious satire, political critique, and the boundaries of free speech at the center of public discourse in Russia.

The video footage itself, however, was far from remarkable in terms of the audience reached: two years after the performance, the number of views on YouTube did not exceed 3 million, a figure hardly comparable to that for videos considered viral (Broxton et al.). While the video footage did find its way to a wider audience by other means, such as TV broadcasts or pictures in newspapers, the lyrics were usually mentioned in passing, with references not going far beyond citing the title of the prayer. When demonstrated on mainstream Russian TV as part of the news reports that covered the trial, the video of the performance was generally accompanied not by the original soundtrack, but by the comments of reporters or experts who most often suggested its blasphemous nature. The clearly provocative visual component of the performance made it an easy target for such interpretations, which led to overlooking the content of the prayer.

One of the rare lengthy readings of the prayer was provided in court, in the form of a 21-page report from the psychological and linguistic experts who supported the prosecutor's case (Feygin) and were cited in the court decision ("Prigovor"). Aiming to refute Pussy Riot's claims that the performance was a political critique and to present the performance as having been motivated primarily by religious hatred, the experts conducted a complicated semantic analysis to argue that the performance was self-evidently "unacceptable” to Russian society, making the report quite an interesting discursive product of its own.

In the independent Russian media and abroad, the performance was usually described - in line with the explanations provided by Pussy Riot in court-as having been targeted at the growing ties between church and state. Yet, even these descriptions were quite understandably devoid of many specifics embedded in the cultural and historical context, which underrated the potential value of the performance for providing insight into the power relations in contemporary Russia that it meant to challenge. Recent articles (Bernstein, Denysenko, Prozorov, Storch) and books (Brysk, Gessen) have attempted to contextualize Pussy Riot's performance and the political discourse they oppose by looking at them through the lenses of parody, profanation, body politics, law, and even the concept of "holy fools" in the pattern of Christian prophets. This article contributes to this discussion by conducting a comparative analysis of the Pussy Riot text and the experts' report as its discursive opponent.

Through a critical discourse analysis of the original lyrics of the "punk prayer" and the expert report, this article demonstrates that, although they both describe the case as a struggle between the alliance of state and church, on the one hand, and the 
opponents of these close ties, on the other, their discursive devices and rhetorical strategies serve opposite goals. The prayer challenges the social norms sustained by the state and religious authorities, while the report intends to naturalize these norms and discredit religiously contextualized political protests as crossing the boundaries of legitimate public debate.

\section{Critical Discourse Analysis}

In its theoretical framework, this research is guided by critical discourse analysis. Drawing on insights from linguistics, semiotics, literary theory, social cognition, rhetoric, cultural studies, and other disciplines, critical discourse analysis does not offer a single set of analytical tools but instead can be viewed as an umbrella term for denoting an approach to studying discourse as "talk and text in social practice" (O’Reilly et al. 249). What unites critical discourse analysts regardless of their methodological preferences is the view of language as a product of and tool for social construction: "language both shapes and is shaped by society" (Machin and Mayr 4).

A particular concern of critical discourse analysis is power relations. Language is never neutral. Instead, it should be viewed as a set of resources purposefully chosen by communicators to serve particular ideological purposes (Kress). In this sense, power relations are inherently discursive, that is, they are exercised, practiced - and hence can be studied - through discourse (Fairclough and Wodak). The purpose of critical discourse analysis is therefore to expose the underlying ideology of texts by asking what types of power interests are "buried" in them and "what possible ideological goals they might serve” (Machin and Mayr 5). Central to this theoretical endeavor is a focus on the role of discourse in the "(re)production and challenge of dominance" (Van Dijk 249) and power abuse. The latter is defined as "breaches of laws, rules and principles of democracy, equality and justice by those who wield power" (Van Dijk 255). This makes critical discourse analysis a particularly relevant theoretical framework for analyzing both the "punk prayer," which explicitly challenged what the Pussy Riot members viewed as the abuse of political power by Putin and the Russian Orthodox Church, and the experts' report, which, in view of the questionable fairness of the verdict (Kananovich), was viewed by critics as a contributor to legitimizing this abuse. The aforementioned diversity of methodological tools used by critical discourse analysis (Blommaert and Bulcaen 450) provides researchers with flexibility in choosing those research questions and procedures that are most applicable to the topic under study.

Aiming to reveal whose power each of these texts intends to challenge or sustain, the first question that needs to be asked is which social actors these texts vest with agency. Defined as "the socioculturally mediated capacity to act" (Ahearn 112), the concept of agency introduces a useful distinction between an actor, a person whose actions are rule-governed or rule-oriented, and an agent, a person who is engaged in the exercise of power as (re)constituting the world (Karp 137) and not "just following orders" (Moses 205). According to some theorists, possessing agency is inevitably associated with resistance to the status quo (Goddard 3) and domination (Frank 286). Although some other theorists have questioned the usefulness of addressing 
agency within a dualistic framework, “one in which norms are conceptualized on the model of doing and undoing, consolidation and subversion” (Mahmood 23), oppositional agency remains one of the most prominent forms of exercising agency in texts (Ahearn 115), making it reasonable to frame the first research question as follows:

RQ1: What social actors are portrayed in the texts as possessing agency? In cases of the limited or absent agency of certain actors, whose power is presented as constraining their capacity to act?

The second research question is closely related to the specific aim of this study of exploring rhetorical strategies employed in the texts to sustain or challenge the existing boundaries of legitimate public debate. One particular strategy appears to be of particular relevance here. Provisionally called "the strategy of naturalizing," it refers to the idea of language as an ideological instrument that is used to create, maintain, and legitimize certain types of social practices by presenting them as normal, neutral, and taken-for-granted (Machin and Mayr 5), (Van Dijk 250) and, vice versa, condemning the practices that challenge the promoted way of action as being unnatural and contradictory to common sense. Therefore, the following question can be asked:

RQ2: What social practices are presented in both texts as (un)natural and (ab)normal?

Finally, approaching language as a set of resources to achieve a particular ideological purpose demands studying not only the manifest content presented in the text but also the content that could have been reasonably expected to be there but is absent (Fairclough) and can only be revealed - using Machin and Mayr's term - "by looking for absences” (2). This rhetorical strategy of exclusion can be studied by asking the following question:

RQ3: What contextual aspects of the Pussy Riot performance relevant to decoding its message are absent from the texts? What ideological explanations do these absences suggest? ${ }^{2}$

\section{In Search of Agency}

The Pussy Riot prayer, according to its almost literal translation from Russian into English provided by the band members themselves ("Alekhina and Others v. Russia”), reads as follows:

Virgin Mary, Mother of God, drive Putin away

Drive Putin away, drive Putin away

Black robe, golden epaulettes

Parishioners crawl to bow

The phantom of liberty is in heaven

Gay pride sent to Siberia in chains 
The head of the KGB, their chief saint,

Leads protesters to prison under escort

So as not to offend His Holiness

Women must give birth and love

Shit, shit, holy shit!

Shit, shit, holy shit!

Virgin Mary, Mother of God, become a feminist

Become a feminist, become a feminist

The Church's praise of rotten dictators

The cross-bearer procession of black limousines

A teacher-preacher will meet you at school

Go to class - bring him cash!

Patriarch Gundyay ${ }^{3}$ believes in Putin

Bitch, better believe in God instead

The belt of the Virgin can't replace rallies

Mary, Mother of God, is with us in protest!

Virgin Mary, Mother of God, drive Putin away

Drive Putin away, drive Putin away.

Studying the Pussy Riot prayer through the lens of the first research question reveals that almost all social actors are denied agency there. The prayer starts with the statement, "Parishioners crawl to bow," which uses verbs with a clear servile connotation. While bowing is an element of the Orthodox veneration ritual (Agapov), crawling, although found in some celebrations ("V Tutaeve"), is predominantly practiced as an element of the monastic tonsure ceremony (Ilarion) and can hardly be considered a component of parishioners' typical routines. This phrasing suggests both the metaphoric nature of this rhetorical device and its intention to emphasize the submissiveness expected of Orthodox believers and the lack of agency accorded to them.

A second social group that has to meet certain expectations is that of women, who, according to the prayer, "must give birth and love." The actual decisions made by women are omitted from the narration and are not the subject of any serious discussion or consideration; it is unclear whether they decide to resist, negotiate, or acquiesce to these hegemonic gender norms. The focus is placed on the standards themselves to which women are held, "giving" rather than receiving love. This interpretation is emphasized by the ending of the phrase - as it turns out, "women must give birth and love / In order not to offend His Holiness." Referred to here by his church title, the Head of the Russian Orthodox Church Patriarch Kirill I of Moscow is presented as possessing the ultimate regulatory and motivational power. However, this turns out to be a hasty conclusion, for according to the last verse of the prayer, there is someone else whose power this allegedly almighty head of the church accepts as being even more significant than his own. This someone is not God: "Patriarch Gundyay believes in Putin.” Remarkably, the name by which the Patriarch is addressed in this verse is not his official title, by which he is referred to in the previous verses that were meant to reinforce his power. Neither is it his church name, 
Kirill. The name used here is a pejorative, derisive version of his secular name, Gundyaev, which was widely used in Russian social media (“Gundyay”, Lebedev).

By putting the head of the state above the head of the church and equating him with God (note the full version of the excerpt, "Patriarch Gundyay believes in Putin / Bitch, better believe in God instead"), the text evokes the long tradition of the sacralization of the monarch in Russia. The idea of parallelism between the monarch and God was borrowed from Byzantium as part of the Christianization of the Russian state, but it went much further than that, up to the monarch's assimilation of the functions of the head of the church, which made the sacralization of the monarch a part of the state mechanism (Uspenskij and Zhivov 78). By evoking the similarities between the absolute power of the monarch in the Russian Empire and that of Putin in contemporary Russia, the text portrays him as the regulatory and oppressive agent.

This idea is supported further by the following verse: "The head of the KGB, their chief saint, / Leads protesters to prison," portraying Putin, a former head of the KGB's successor, the $\mathrm{FSB}^{4}$, as the agent who can take away freedom in the literal sense. Notably, those who are led by Putin to prison as well as those described in a similar statement, "Gay pride [that is, members of the LGBT community] sent to Siberia ${ }^{5}$ in chains," are portrayed in the prayer as the only actors who consciously resist domination and can therefore be considered agents in the strictest understanding of this term.

In this situation, when those who, besides Putin, possess agency and have to pay for it with their freedom, the authors of the prayer turn to the figure whose power has not yet been contested in the text and who could therefore challenge Putin's domination - the Virgin Mary, by famously asking her to "drive Putin away."

Even more interesting results are revealed in the close reading of the experts' report. Using Halliday's classification of verbs as representing action, the report portrays the Pussy Riot members as active "doers" of not only behavioral processes (according to the report, they "sing, dance, cry"). While this portrayal may be explained as an intent to merely lay out the facts of the case, it also describes mental and material processes with clearly negative connotations: "humiliate, violate, commit." By doing so, the report constructs the Pussy Riot members as "focalisers" of action and allows them "an internal view of themselves” (Machin and Mayr 107). Usually, this discursive device encourages empathy with the actors by humanizing them in the eyes of the reader. This is not what the report intends to achieve. By claiming to be providing insight into the actual motivations of the Pussy Riot members and presenting those as inherently violent and destructive, the report uses this device for exactly the opposite effect.

In addition to the Pussy Riot members, one would expect a strong position of agency from the authors of the report. Despite being informed by scholarship, the report is understood by Russian law as presenting the personal opinions of experts as individual, independent consultants. Neither their religious affiliations nor their institutional interests should affect their view of the case, which should supposedly take away the burden of any factors that might constrain their independent decision making and allow them to freely express their professional judgment. The more remark- 
able it is that throughout the entire report, the experts - using Van Leeuwen's term are de-agentalized (96) by not being referenced in the text as the "doers" of the decision making process. Examples of sentences in which they present their findings include "the analysis of the lyrics reveals ..." and "the examination of the performance allows to identify ..." The use of the nominalization "analysis" and "inquiry" instead of alternative options like "We analyzed the lyrics and concluded..." or "We examined the performance and identified..." conceals the agent of the action and presents the latter as an abstract, objective, dehumanized activity existing in its own right and being uninfluenced by the personal or institutional interests of the authors of the report.

The only section of the report that does mention the experts' names is the one where it cannot be avoided by definition - the preamble, a mandatory section that assigns the responsibilities to each member of the expert team. Even here, the report uses passive verbs: "the answer to questions 1 and 2 was given by ... Abramenkova," which results in "backgrounding" and decentering the experts from their actions.

A similar discursive device is used in the section that concerns one of the most heavily criticized aspects of the prosecution's case (Kananovich) used to prove the presence of the two defining elements of criminally punishable hooliganism in the Pussy Riot performance: the manifestation of the patent contempt of society (as an aspect of actus reus) and the motive of religious hatred (as a part of mens rea). Without proving the presence of these elements, the prosecution's claim that Pussy Riot's actions are criminal should have been refuted by the Court and been transformed into an administrative offense. To prove the presence of these elements, the prosecution posed two separate questions ${ }^{6}$ to the experts that demanded two independently justified answers. On the contrary, however, the experts elected to combine them within one answer. The rhetorical devices chosen to justify this otherwise unexplained decision are particularly revealing: "[In view of the circumstances of the case], it was considered to be reasonable and appropriate to combine the examination of the materials within the first and second questions." Presented this way, the exact circumstances that would justify the violation of the legal decision making logic remained backgrounded. Using the words "reasonable" and "appropriate" without specifying what exactly makes the experts' decision reasonable and what makes it appropriate gives the impression of being detailed, well-thought-out, and precise, without being such, and presents the rhetorical strategy of "strategic ambiguity" (Wood and Kroger). Similarly concealed remains the agent responsible for "considering," which, once again, removes the sense of agency from the process of this questionable decision making.

In fact, the only actor whom the report portrays as possessing the agency strong enough to oppose the negatively connoted agency of Pussy Riot is the State. According to the report, the State "respects the norms set by religious institutions" and "support[s] the rules [of public behavior in religious buildings] with legal norms," thus playing the patronizing role of the agent who sets the rules of the game and ensures the proper behavior of society members for the public good. In this situation, the report presents the case as a struggle between evil disrupters of social order and a 
fair, though strict, protector of the public peace.

\section{Portraying as (Un)Natural as a Rhetorical Strategy}

The rhetorical strategy undertaken by Pussy Riot can be described as a purposeful juxtaposition of opposites, or - using the term of the report - a "combination of the sacred and profane.” Little in the text is portrayed as being natural and commonsensical, starting with the very title of the song, "punk prayer." It combines punk, a movement known for its anti-establishment philosophy and promotion of individual freedom in a visually provocative way (Kugelberg and Savage), with prayer, an intimate, inwardly oriented activity and a hallmark of the Orthodox religion built on the principles of conciliarism, or sobornost, a loving, caring fellowship of believers, "the community of faith," which cannot be divided and where "bishops, priests and laity all together constitute the people of God” (Arola and Saarinen 132), condemning the very excessive individualism that is promoted by punk.

This contrast sets the tone for the entire text. One line of the prayer starts with the words, "Black robes," referring to the plain vestment of Orthodox priests and monks. Indeed, the very etymology of the word robe (or ryasa in Russian) refers to the Latin word rado, which means "wear shabby, threadbare clothes” (Golubinsky 572) and should evoke associations with ascetic votaries of God who renounce any of the joys of the secular life. Yet, the ending of the line puts the plausibility of this idealistic image in doubt. In the words "Black robes, golden epaulettes," the golden color of the clerical dress worn by Orthodox priests during the liturgies ("Tsveta") that are public events worshipping God is placed in opposition with articles of military clothing (epaulettes) that are symbols of a commitment to protect the interests of the state.

A similar effect is ensured by the line that starts with the words "the cross-bearer procession," evoking associations with the Orthodox tradition to gather believers for a communal outdoor ceremony of bearing the cross or other relics while singing prayers and hymns (Purtov). This event is intended to make its participants equal in God's eyes regardless of their background and economic status. Once again, however, the ending of the line challenges this canonical image. The cross-bearer procession turns out to consist of "black limousines," suggesting that some people are "more equal than others" in gaining God's favor. This image refers to the criticism raised by the independent press and social media users against the alleged participation of the Church management in importing alcohol and tobacco products (Soldatov), expensive possessions such as exclusive watches ("Patriarkh Kirill Nosit”), a yacht ("Yachta"), luxurious motorcades (Soldatov), and favoring some parishioners over others by allowing top-ranking officials to venerate Orthodox relics without having to stand in a queue ("Power of Attraction"). Notably, this line of reasoning was continued by the Pussy Riot members in their public appearances, one of which was quoted in the court decision:

"This [the Cathedral of Christ the Savior] is not a house of God, but the office of the ROC [Russian Orthodox Church]. We officially came to the office of ROC to express our thoughts. The Ca- 
thedral of Christ the Savior looks not like a place of spiritual life, but like a business center: banquet room leased for big sums [of money], dry cleaners, laundry, secured parking space...” ("Prigovor")

This deliberate contrast between the canonical representations of religious devotion and the overtly unrighteous and self-interested behavior of Church leaders is a strategy intended to challenge the social norms sustained by the authority of the Orthodox Church.

The experts' report uses a completely different strategy, "naturalizing” the close ties between the church and state while inflating the "taken-for-grantedness" of the unacceptability of Pussy Riot's actions. The discursive devices used to that end appear early in the report, in the section "Circumstances of the Case," which is intended to merely outline the factual information pertaining to the issues under study. However, this section describes the Pussy Riot members as wearing "provocatively bright balaclavas," an evaluative judgment with a clearly negative connotation.

To boost the validity of their arguments, the experts appeal to what they call a "fact of common knowledge" and a "fact that does not need proof" and precede their conclusions with constructs such as "their [Pussy Riot's] actions cannot be viewed other than ..." This tactic is surprising, as it is usually the job of experts to provide accounts that go beyond commonsense clarifications as well as to challenge them with alternatives to ensure that their explanation of the motives and the consequences of the Pussy Riot performance is the most reasonable one. However, the use of these discursive devices makes more sense when looked at as a purposeful strategy guided by the consideration that such language choices "make the [decision making] process appear as neutral and more objective once presented as a fact” (Machin and Mayr 140). By pursuing this strategy, the experts gloss over the fact that some of these "factual conclusions" are actually their personal interpretations. Finally, the abundance of references to the obviousness and "naturalness" of the findings can be viewed as an example of "overlexicalisation," which usually serves as evidence of an "attempt to over-persuade" (Machin and Mayr 222). Remarkably, one of the constructions that utilizes the very same strategy, "[the Pussy Riot actions] were quite definitely a gross violation of public order," is meant to justify another very problematic argument in the prosecution's case, which is that the violation of public order caused by the Pussy Riot performance was gross and therefore was subject to criminal, instead of much more lenient administrative, prosecution. By labeling this highly contestable conclusion as "quite definite," the experts are trying to suggest that it is not open to debate.

In view of these numerous references to the obviousness of their conclusions, it seems particularly significant that some truly obvious aspects of the Pussy Riot performance escape the experts' attention or yield a rather farfetched interpretation. For example, the unambiguous mentioning of the Patriarch in the "punk prayer" is not addressed by the experts at all. Instead, this Pussy Riot criticism is presented as being targeted against Orthodox priests as a social group, based on the constructions "black robe" and "a teacher-preacher will meet you at school." Indeed, a singular 
noun functions here as a stylistic device, widely used in the Russian language to describe a group of people, who would normally be denoted with a plural noun, in order to make that description more aphoristic and expressive (Golub). However, overlooking the parts of the prayer that explicitly mention the name of the Head of the Church, for example in the above cited line "Patriarch believes in Putin," in the twenty-one page document produced as a result of the close reading of the one-page lyrics of the prayer suggests that it has been a strategic omission.

Similarly strategic appears to be the experts' failure to recognize the "prayer's implicit references to Putin. For example, the above-cited line "The head of the KGB, their chief saint" is interpreted not as a reference to Putin as the former head of the agency that functionally succeeded the KGB but to the Russian security services in general and a slander against Orthodox priests. Central to this strategy is the experts' decision to analyze this construction partially, without the ending - "Leads protesters to prison," which allows them to conclude that the prayer "does not use any offensive words and expressions toward Putin (as compared to the other mentioned persons.” The failure to recognize the prayer's criticism of Putin's actions, such as silencing political opponents or encouraging the further interpenetration of the church and state by providing the Orthodox Church with access to educational institutions, results in the conclusion that the political motive claimed by Pussy Riot was absent from the performance. According to the experts, the only part of the prayer that suggests the political motivation is the refrain "Virgin Mary, drive Putin away," which "looks completely extraneous and out of the context of the song, the content of which is devoted to insulting and humiliating not Putin, but the social group of Orthodox believers" and which "is highly likely to have been used ... in order to artificially position the action as a political protest.”

Portraying the Pussy Riot performance as criticizing not the activities of particular personalities such as the Patriarch and Putin but as "insulting and humiliating" a broad group of Orthodox believers - if not all citizens of the country, who, according to the report, "respect traditional religions of Russia as an important element of social life, history, and culture" - serves to marginalize Pussy Riot. By playing on the "us vs. them" divide and presenting their actions as deviating from norms followed by the majority of the population, who supposedly exceed the supporters of Pussy Riot both numerically and in "spiritual wealth," the report delegitimizes their performance and presents it as crossing socially acceptable boundaries.

\section{Looking for Contextual Absences}

The Pussy Riot performance is a visually provocative and intellectually challenging form of theatre that requires the reader and the viewer to be familiar with the Russian social, political, and cultural context to be able to decode its message. Staged in the full swing of the presidential campaign, the prayer invoked references to the recent public and political events that had been associated with Putin as a candidate in that campaign.

The above-mentioned line "A teacher-preacher will meet you at school / Go to class - bring him cash" is one of such examples. In 2010, the government approved 
teaching religion in the schools of twenty regions of Russia by allowing parents to decide whether their children would learn either the basics of religion or secular ethics ("Rasporiazhenie"). In 2012, this practice was extended to the rest of Russia ("Poruchenie"). Two weeks before the performance and less than a month before the day of the election, the Patriarch hosted a meeting with Putin and called him "surely the most likely" winner of the presidential race ("Stenogramma”). The heads of the other three religions legally recognized in Russia as traditional were also invited by Patriarch "to discuss the future of the country [with Putin] in, first of all, his capacity as a presidential candidate.” At the meeting, which was covered by the mainstream Russian media as evidence of Patriarch's direct support ("Patriarkh Kirill Podderzhal") and blessing (Novikova) of Putin - or, to cite the prayer, "[t]he Church's praise of rotten dictators" - the latter publicly assured the religious leaders of his commitment to provide them with access to governmental funding and widen their media presence ("Stenogramma").

Similarly multi-layered is the line "The belt of the Virgin can't replace rallies," which evokes references to the official address by the Patriarch to Orthodox believers three weeks before the performance. Referring to the anti-government protests that had been held in Moscow and other Russian cities during the presidential campaign (Barry and Kramer), he warned his parishioners against going into the streets by offering a more acceptable way of expressing their concerns: "Orthodox believers cannot go to manifestations - they are standing in queues to [venerate the Orthodox relic of] the Belt of the Virgin" and "pray in the silence of cloisters, in monastic cells, at home" (Intro). According to Patriarch, political protests should make the heart of pious believers "bleed" and "draw in their minds clear historical parallels with dissipation and frenzy of prerevolutionary years, with disorder, confusion, and destruction of the country in the 1990s" ("Slovo"). By evoking references to the political protests that happened soon before and after the USSR's collapse and portraying them not as evidence of the political awakening and civic activism of Soviet citizens but as "disordering, confusing and destructing" events - much in line with the pro-Soviet nostalgic rhetoric employed by Putin - the Patriarch attempts to delegitimize public political protests and push them beyond the boundaries of socially acceptable forms of citizens' civic participation.

Pussy Riot's punk prayer is densely packed with political references, which contrasts with the experts' strategy of glossing over the contextual aspects of the performance in their report. One would expect that the analysis of the performance that claimed to be political would include at least some references to the political context in which it was staged. Yet, this is not what happens in the report. Neglecting to mention that the performance was staged during the election campaign is particularly telling, considering the marked attention that the report gives to discussing the likely motivation and consequences of Pussy Riot's choice of the venue.

Much in line with this strategy, the report notes the religious and historical nuances of the Cathedral's interior details, including the memorial plaques commemorating the soldiers who died during the 1812 Napoleonic war, but remains vague about the details of the current political and social climate in Russia. This lack of specificity serves the same delegitimizing function. By decontextualizing the Pussy Riot 
performance, the text suggests that their "deviant actions" can be neither explained nor excused - a typical strategy used to discredit powerless groups, emphasize their threat to the interests of the dominant group, and sustain the existing power relations (Van Dijuk 263-5).

\section{Conclusion}

This article examines the discourse surrounding the acceptability of religiously contextualized political speech in contemporary Russia by conducting a critical discourse analysis of two texts related to the high-profile Pussy Riot blasphemy case: the original lyrics of the "punk prayer" performed in the Cathedral of Christ the Savior and the report from the psychological and linguistic experts that formed the basis of the prosecutor's case.

As this analysis makes clear, the rhetorical strategies employed by the texts serve two opposing goals: the prayer challenges the existing power relations in Russia while the report intends to sustain them and delegitimize Pussy Riot's political protest. These intentions are evident in the strategic use of the discursive devices of both texts.

By describing the social and political climate in Russia, Pussy Riot's punk prayer portrays two actors as possessing (besides the Virgin Mary) the strongest agencies: Putin and his political and ideological opponents who, as opposed to the other social actors who are constrained in their capacity to act by religious or hegemonic gender norms, have the capacity to resist his dominance, even though at the cost of their freedom. Despite the use of completely different discursive devices, this layout of social forces resonates with the one resulting from the close reading of the experts' report. As in the prayer, the report presents the case as an ideological interplay between two conflicting sides: the state, committed to protecting social peace and respecting religious values, and the Pussy Riot members, who are portrayed as opponents of this supposedly natural alliance between the church and state.

In its attempts to discredit Pussy Riot and their supporters, the report employs an array of tactics to inflate the "taken-for-grantedness" of the unacceptability of their actions, ranging from calling upon common sense and facts "that do not need proof" to emphasize the minority position of Pussy Riot in Russian society and arguing that it was targeted not at particular individuals such as the Patriarch and Putin but at Orthodox believers and citizens of Russia in general. By playing on the "us vs. them" divide and presenting the actions of Pussy Riot as deviating from the norms accepted by the majority of the population, the report marginalizes them as abnormal and perverse.

The overlexicalization used by the report to persuade the reader of the gravity of the damage caused by the Pussy Riot performance is in sharp contrast to the report's failure to describe the political context in Russia that is necessary to understand the prayer's references to recent political and social events and to reveal its political, rather than blasphemous, nature.

The implications of the report's rhetorical strategy go beyond this individual case. By decontextualizing and depoliticizing the performance, which was repeatedly 
claimed by Pussy Riot members and supporters to be addressing issues of public concern, the report trivializes its message and suggests that the damage caused by this and other instances of religiously contextualized political speech cannot be justified.

According to Sapir, "Different languages ... shape the world differently. So the worlds different language speakers inhabit are not simply ones with different labels but are therefore distinct worlds" (209). If applied to the findings of the critical discourse analysis presented in this article, this argument suggests that Pussy Riot's punk prayer and the experts' report on it portray two distinct Russias. The Russia advocated by the prayer is the one where no authority, political or religious, is taken for granted; where any opinion, no matter how socially acceptable it is claimed to be, can and should be contested; and where a riot is a way of dealing with a state that has not created easily accessible sites for public discussion. The Russia of the experts' report, however, has a small, and shrinking, space for acceptable public debate, where religion is used as a tool to neutralize threats to the established power relations, and where civil obedience is promoted as a safe, natural, and legitimate modus operandi for citizens.

\section{Notes}

1 The prayer employed the opening melody and refrain of the famous "Rejoice, Mother of God” from the “All Night Vigil” by Sergei Rachmaninov (Denysenko 1071).

2 I organize my presentation of the findings around these three research questions, emphasizing that my primary interest is in the analysis of the strategies used by these texts, rather than their normative evaluation.

3 This is the form of the Patriarch's name used in the original Russian version of the prayer. The absolute majority of the English language translations of the prayer (Denysenko 1069; Gessen 118), including those provided by the Pussy Riot members themselves ("Alekhina and Others v. Russia”), used the actual, not derogatory, version of the Patriarch's secular name. Given the focus of this article, I use for analysis the literal translation of the original version.

4 Federal'naya Sluzhba Bezopasnosti Rossiyskoy Federatsii, FSB / Federal Security Service of the Russian Federation.

5 Siberia has historically been a place of political exile and imprisonment of the government’s opponents in Russia (Gruszczynska and Kaczynska 106).

6 The first question asked “whether the Pussy Riot's actions can be viewed as gross violation of generally accepted norms and behavior standards manifesting patent contempt of society and/or a particular social group” (Feygin) and was meant to reveal the presence of the actus reus element of hooliganism. The second one asked "whether these actions can be viewed as motivated by political, ideological, racial, national or religious hatred or enmity with respect to a social group” (Feygin) and referred to another element of criminally punishable hooli- 
ganism - mens rea.

\section{Works Cited}

Agapov, Aleksei. “Chto Pol'zy v Poklonakh?” (“What is Bowing for?”) Pravoslavie i Mir. Pravmir.ru. 15 Feb. 2010. Web. 20 May 2014.

Ahearn, Laura M. "Language and Agency.” Annual Review of Anthropology 30 (2001): 109-37.

"Alekhina and Others v. Russia." European Court of Human Rights. Hudoc.echr.coe.int. 2 Dec. 2013. Web. 20 May 2014.

Arola, Pauliina, and Risto Saarinen. In Search of Sobornost and "New Symphony". The Ecumenical Review 54 (2002): 130-41.

Barry, Ellen, and Andrew E. Kramer. "In Biting Cold, Protesters Pack the Center of Moscow.” New York Times. Nytimes.com. 5 Feb. 2012. Web. 20 May 2014.

Bernstein, Anya. “An Inadvertent Sacrifice: Body Politics and Sovereign Power in the Pussy Riot Affair.” Critical Inquiry 40.1 (2013): 220-41.

Blommaert, Jan, and Chris Bulcaen. "Critical Discourse Analysis.” Annual Review of Anthropology 29 (2000): 447-66.

Broxton, Tom, et al. “Catching a Viral Video.” Journal of Intelligent Information Systems 40.2 (2013): 241-59.

Brysk, Alison. Speaking Rights to Power: Constructing Political Will. New York: Oxford University Press. 2013. Print.

Chilton, Paul. "Metaphor, Euphemism, and the Militarization of Language." Current Research on Peace and Violence 10 (1987): 7-19.

Denysenko, Nicholas. “An Appeal to Mary: An Analysis of Pussy Riot's Punk Performance in Moscow." Journal of the American Academy of Religion 81.4 (2013): 1061-92.

Fairclough, Norman, and Ruth Wodak. "Critical Discourse Analysis.” Discourse as Social Interaction. Ed. Teun A. van Dijk. London: Sage, 1997. 258-85.

Fairclough, Norman. Analysing Discourse: Textual Analysis for Social Research. London: Routledge, 2003. Print.

Feygin, Mark. "Ekspertiza Troitskogo-Abramenkovoi-Ponkina po "Delu Pussy Riot.” ("Report by Troitskii, Abramenkova, and Ponkin in the Pussy Riot Case.”) Livejournal. Livejournal.com. 25 June 2012. Web. 20 May 2014.

Frank, Katherine. “Agency.” Anthropological Theory 6.3 (2006): 281-302.

"Freed Pussy Riot Activists to Start Prisoners' Rights Group." RIA Novosti. En.ria.ru. 27 Dec. 2013. Web. 20 May 2014.

Gessen, Masha. Words Will Break Cement: The Passion of Pussy Riot. New York: Riverhead Books, 2014. Print.

Gillespie, Paula, and Neal Lerner. The Allyn and Bacon Guide to Peer Tutoring. Boston: Allyn, 2000. Print.

Goddard, Victoria Anna, ed. Gender, Agency and Change: Anthropological Perspectives. London, New York: Routledge, 2000. Print.

Golub, Irina. "Stilistika Russkogo Yazyka.” (“Stylistics of the Russian Language.”) Moscow State University of Printing Arts. Hi-edu.ru. n.d. Web. 20 May 2014. 
Golubinsky, Yevgeny. Istoriya Russkoi Tserkvi (The History of Russian Church). Volume 1. Moscow: University Typography, 1901. Print.

Gruszczynska, Beata, and Elzbieta Kaczynska. Poles in the Russian Penal System and Siberia as a Penal Colony (1815 - 1914): A Quantitative Examination. Historical Social Research 15.4.56 (1990): 95-120.

"Gundyay Otzhigaet.” (“Gundyay Rocks”) Livejournal.com. Ruantireligion.livejournal.com. 30 Aug. 2011. Web. 20 May 2014.

Halliday, Michael Alexander Kirkwood. "Types of Process.” Halliday: System and Function in Language. Selected papers. Ed. Gunter Kress. Oxford: Oxford University Press, 1976. 159-73. Print.

Ilarion, Mitropolit. "Obriady Pravoslavnoi Tserkvi." ("Rites of the Orthodox Church.”) Moscow: Eksmo, 2012. Print.

“Jailed Pussy Riot Activists Walk Free Under Presidential Amnesty.” RIA Novosti. En.ria.ru. 23 Dec. 2013. Web. 20 May 2014.

Kananovich, Volha. "Execute Not Pardon”: The Pussy Riot Case, Political Speech and Blasphemy in Russian Law." 97th Annual Conference of the Association for Education in Journalism and Mass Communication. Le Centre Sheraton, Montreal, Canada. 6 Aug. 2014. Conference Presentation.

Karp, Ivan. “Agency and Social Theory: A Review of Anthony Giddens.” American Ethnologist 13.1 (1986): 131-7.

Kress, Gunther. "Ideological Structures in Discourse." Handbook of Discourse Analysis. Ed. Teun A. van Dijk. London: Academic Press, 1985. 27-42. Print.

Kugelberg, Johan, and Jon Savage. Punk: An Aesthetic. New York: Rizzoli, 2012. Print.

Lebedev, Artemy. "Priostanovim Glumlenie Vmeste!” ("Let’s Stop Scoffing Together!”). Livejournal.com. Tema.livejournal.com. 5 Sept. 2012. Web. 20 May 2014.

Machin, David, and Andrea Mayr. How to Do Critical Discourse Analysis: A Multimodal Introduction. Los Angeles, CA, London, New Delhi, Singapore, and Washington, DC: Sage, 2012. Print.

"Madonna Urges Russia to Free Pussy Riot at Moscow Concert.” Reuters. Reuters.com. 8 Aug. 2012. Web. 20 May 2014.

Mahmood, Saba. Politics of Piety: The Islamic Revival and the Feminist Subject. Princeton, NJ: Princeton University Press, 2005. Print.

Matveeva, Garadzha. "Pank-Moleben "Bogoroditsa, Putina Progoni” Pussy Riot v Khrame Khrista-Spacitelia” ("Pussy Riot's Punk Prayer "Mother of God, Put Putin away" in the Cathedral of Christ the Savior"). YouTube. YouTube.com, 21 Feb., 2012. Web. 20 May 2014.

Moses, A. Dirk. "Structure and Agency in the Holocaust: Daniel J. Goldhagen and His Critics.” History and Theory 37 (1998): 194-219.

Nakamura, David, and Rachel Weiner. "White House Weighs in on the Big Story of the Day.” Washington Post. Washingtonpost.com. 17 Aug. 2012. Web. 20 May 2014.

Novikova, Anastasiia. "Putin Poluchil Blagoslovenie na Tretii Srok.” ("Putin Received blessing for his third term.”) Izvestia. Izvestia.ru. 8 Feb. 2012. Web. 20 May 2014. 
“O Pussy Riot i Putine Govorili 86\% Mirovykh Sredstv Massovoi Informacii.” (Pussy Riot and Putin were Talked about by 86 Percent of World Media.) Golos Ameriki. Golos-ameriki.ru, 18 Aug. 2012. Web. 20 May 2014.

“Opublikovano Obvinitel'noe Zakluchenie Pussy Riot.” ("Bill of Indictment in Pussy Riot Case Published.”). Novaya gazeta. Novayagazeta.ru, 19 July 2012. Web. 20 May 2014.

O’Reilly, Michelle, et al. "Doing Accountability: A Discourse Analysis of Research Ethics Committee Letters.” Sociology of Heath and Illness 31.2 (2009): 246-61.

"Patriarkh Kirill Nosit Chasy za 30 Tysiach Evro." ("Patriarch Kirill is Wearing Watches that Cost 30 Thousand Euros.”) Unian Information Agency. Unian.net. 30 July 2009. Web. 20 May 2014.

"Patriarkh Kirill Podderzhal Premiera." ("Patriarch Kirill Supported Prime Minister.”) Vesti Nedeli. Vesti7.ru. 12 Feb. 2012. Web. 20 May 2014.

"Poruchenie Prezidenta Rossiiskoi Federatsii D.A. Medvedeva Pr-2009 VP-P444632." ("Order of the President of the Russian Federation D.A.Medvedev Pr2009 VP-P44-4632.”) Ministry of Education of the Russian Federation. Minobr.orb.ru. 2 Aug. 2009. Web. 20 May 2014.

"Power of Attraction: Pilgrims Flock to Our Lady's Belt.” RT. Rt.com. 26 Nov. 2011. Web. 20 May 2014.

“Prigovor Pussy Riot.” (“Pussy Riot Verdict.”) Snob. Snob.ru. 22 Aug. 2012. Web. 20 May 2014.

Prozorov. Sergei. "Pussy Riot and the Politics of Profanation: Parody, Performativity, Veridiction.” Political Studies (2013): n. pag. Web. 1 July 2014.

Purtov, Yevgeny. "Istoria Krestnykh Khodov." ("History of Cross Bearing Processions.”) Russkaya Nedelya. Russned.ru. n.d. Web. 20 May 2014.

"Pussy Riot Supporters around the World Protest against Prison Sentence - in Pictures.” Guardian. Theguardian.com, 17 Aug. 2012. Web. 20 May 2014.

"Rasporiazhenie Pravitel'stva Rossiiskoi Federatsii.” (“Order of the Government of the Russian Federation.”), Rossiiskaia Gazeta. Rg.ru. 29 Oct. 2009. Web. 20 May 2012.

Sapir, Edward. “The Status of Linguistics as a Science.” Language 5.4 (1929): 20714.

"Slovo Sviateishego Patriarkha Kirilla v tretiiu godovschinu intronizacii v Khrame Khrista-Spasitelia.” ("Speech of Holiness Patriarch Kirill in Commemoration of the Third Anniversary of his Enthronement in the Cathedral of Christ the Savior." Moscow Patriarchate of the Russian Orthodox Church. Patriarchia.ru. 1 Feb. 2012. Web. 20 May 2014.

Soldatov, Alexander. "Za Chto Pabu Boziemu Kirillu Blagodarit' "Raba na Galerakh." ("What for Should Servant of God Kirill Be Grateful to the "Galley Slave.”) Novaya Gazeta. Novayagazeta.ru. 14 Feb. 2012. Web. 20 May 2014.

"Stenogramma Vstrechi Predsedatelya Pravitel'stva RF V.V. Putina so Svyateishim Patriarkhom Kirillom i Liderami Traditsionnykh Religioznykh Obschin Rossii.” ("Transcript of the Meeting of Chairman of the Government of the Russian Federation V.V. Putin with His Holiness Patriarch Kirill and the Leaders of the Traditional Religious Communities of Russia.”) Moscow Patriarchate of the Russian Orthodox Church. Patriarchia.ru. 8 Feb. 2012. Web. 20 May 2014. 
Storch, Leonid. "The Pussy Riot Case: Anti-Westernism in the Paradigm of the Beilis Trial.” Russian Politics and Law. 51.6 (2013): 8-44.

Tsoi, Yulia and Anton Ledniov. "Zaschita Samutsevich: Drugie iz Pussy Riot Tozhe Mogli Poluchit’ Uslovno.” (“Samutsevich’s Defense: Others from Pussy Riot Could Have also Had their Term Converted into a Suspended Sentence.”) Izvestia. Izvestia.ru. 10 Oct. 2012. Web. 20 May 2014.

"Tsveta Bogosluzhebnykh Oblachenii.” ("Colors of Liturgical Church Attire.”) Mgarsky Monastery. Mgarsky-monastery.org. n.d. Web. 20 May 2014.

Uspenskij, Boris, and Victor Zhivov. "Tsar and God” and Other Essays in Russian Cultural Semiotics. Boston: Academic Studies Press, 2012. Print.

“V Tutaeve Sostoitsia Krestnyi Khod s Unical'noi Ikonoi Vsemilostevogo Spasa.” ("A Cross Bearing Procession with The Unique Icon of the Most Merciful Savior will be Held in Tutaev.”) Pravoslavie. Pravoslavie.ru. 3 Aug. 2005. Web. 20 May 2014.

Van Dijk, Teun A. "Principles of Critical Discourse Analysis.” Discourse and Society 4.2 (1993): 249-83.

Van Leeuwen, Theo. "Representing Social Action.” Discourse and Society 6.1 (1995): 81-106.

Wood, Linda A., and Rolf O. Kroger. Doing discourse analysis: Methods for studying action in talk and text. Thousand Oaks, CA: Sage, 2000. Print.

"Yachta Patriarkha Kirilla Okazalas’ Podarkom Lukoila." ("Patriarch Kirill's Yacht Proved to Be Gift from Lukoil.”) Polit-online. Politonline.ru. 19 June 2011. Web. 20 May 2014.

"Yoko Ono Awards Peace Prize to Pussy Riot.” Australian Broadcasting Corporation. Abc.net.au. 22 Sep. 2012. Web. 20 May 2014. 